\title{
RESEPSI MASYARAKAT MILENIAL TERHADAP PESAN DAKWAH MELALUI MEDIA SOSIAL DI KABUPATEN BONE
}

\author{
SULFIKA \\ Pascasarjana UIN Alauddin Makassar \\ Email: Sulfikafhyka@gmail.com
}

\begin{abstract}
:
The main problem in this study is the acceptance of millennial society towards the message of da'wah through social media in Bone District? The results of this study indicate that the multimedia propaganda model on social media currently has many variations that allow people to listen to preaching whenever and wherever they are. Among the models of preaching include: Audio Visual / video, Images and Animation. Audio visual is a da'wah model that displays sound and images (in video format). Some social media users feel the rampant Islamic material they read on social media links, make them more interested in studying Islam, feel they have a better understanding of Islam, and feel their daily behavior is becoming more in line with Islamic guidance. Islamic material on social media is also considered helpful for those who feel they have limited time to attend the study forums.
\end{abstract}

Keywords : Millennial Society, Preaching Message, Social Media

\section{PENDAHULUAN}

Perkembangan teknologi melahirkan fenomena menarik dalam kehidupan masyarakat dewasa ini, yaitu maraknya budaya global dan gaya hidup serba instan. Fenomena ini terjadi sebagai dampak dari arus globalisasi yang sudah tidak bisa dibendung lagi. Globalisasi sering dimaknai sebagai hegemoni negara-negara maju (Barat) terhadap negara-negara terbelakang atau bangsa yang sedang berkembang. Mulai dari gaya berpakaian hingga gaya hidup, serta mengkonsumsi makanan instan hingga menyerap berita secara instan tanpa nalar kritis. Salah satu fenomena penting proses globalisasi telah melahirkan generasi gadget, istilah yang digunakan untuk menandai munculnya generasi milenial. ${ }^{1}$

Hadirnya akses internet merupakan media yang tak bisa dihindari, karena telah menjadi suatu peradaban baru dunia informasi dan komunikasi global. Dengan adanya akses internet, maka sangat banyak informasi yang dapat dan layak diakses oleh masyarakat internasional, baik untuk kepentingan pribadi, pendidikan, bisnis, dan lain-lain. Di mana munculnya jaringan internet dianggap sebagai sebuah revolusi dalam dunia komunikasi dan informasi. ${ }^{2}$

Perkembangan internet di Indonesia, memperlihatkan tren perkembangan yang relatif sama, yakni relatif meningkat. Jika dibanding tahun sebelumnya,

${ }^{1}$ Iffah Al Walidah, “Tabayyun Di Era Generasi Millennial”, Jurnal Living Hadis, Vol. 2 Nomor 1, http://ejournal.uin-suka.ac.id/ushuluddin/Living/article/view/1359 ( Oktober, 2017), h. 138.

${ }^{2}$ Nurhidayat Muh. Said, Dakwah dan Berbagai Aspeknya, h. 124. 
pengguna internet di Indonesia mengalami peningkatan jumlah pengguna hingga 34 persen. Sementara itu, penetrasi yang diperlihatkan oleh para pengguna media sosial dengan peningkatan sebesar 30 persen dibanding tahun sebelumnya. Data ini memberikan informasi penting tentang perkembangan penggunaan internet di kalangan masyarakat Indonesia. ${ }^{3}$

Dakwah melalui media massa dimulai sejalan dengan perkembangan teknologi mulai berkembang yakni sejak abad ke-21. Dahulu kala dakwah dilakukan dengan tatap muka langsung secara personal ataupun berkelompok. Sesuai dengan perkembangan zaman dan teknologi informasi kini dakwah bisa dinikmati tidak hanya pada satu tempat atau oleh satu kelompok saja namun bisa dinikmati oleh seluruh dunia dan kalangan. ${ }^{4}$

Pengembangan dakwah melalui media diaplikasikan bahwa dakwah dalam Islam adalah suatu kewajiban yang mutlak dilaksanakan oleh setiap muslim menurut kemampuan yang dimilikinya, Allah berfirman dalam QS. Fussilat/41: 33.

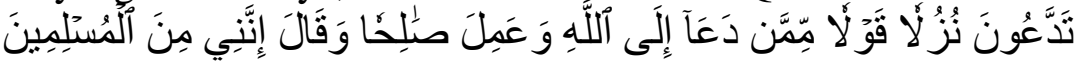

Terjemahnya:

Siapakah yang lebih baik perkataannya daripada orang yang menyeru kepada Allah, mengerjakan amal yang saleh, dan berkata: "Sesungguhnya aku termasuk orang-orang yang menyerah diri?"5

Kemajuan IPTEK masa kini dapat memengaruhi aktivitas dakwah yang dilakukan oleh para pelaku dakwah. Oleh karena itu, dakwah masa kini sudah seharusnya dikemas dalam berbagai metode yang efektif sesuai dengan kondisi objeknya. ${ }^{6}$

Dalam aplikasi penyampaian dakwah, seorang da'i sebagai subjek dakwah memerlukan seperangkat pengetahuan dan kecakapan dalam hal metode. Dengan mengetahui metode maka da'i mampu memahami dan menyampaikan materi kepada objek dakwah yang sedang dihadapinya dengan harapan bahwa mampu diterima dan dipahami pula oleh ${\text { mad' } u .^{7}}^{7}$

Era milenial menuntut kecepatan dan kemudahan dalam mengakses informasi. Generasi milenial saat ini sangat tidak mungkin untuk tidak mengenal dan memiliki sosial media yang dapat mengakses informasi. Bahkan lebih mudah mencerna atau memahami dakwah yang disampaikan melalui media social ketimbang mendengarkan langsung ceramah dari dai yang di atas mimbar. Maka tulisan ini dimaksudkan untuk mengkaji bagaimana generasi milenial bisa memahami dakwah melalui media sosial.

Penyampaian pesan-pesan agama melalui cara tradisional (ceramah di atas mimbar) saat ini telah mengalami pergeseran dan kadang menempatkan agama

\footnotetext{
${ }^{3}$ Moch. Fakhruroji, Dakwah di Era Media Baru: Teori dan Altivisme Dakwah di Internet (Bandung: Simbiosa Rekatama Media, 2017), h. 31.

${ }^{4}$ Firdaus Muhammad, Jurnalistik Profetik Konseptualisasi Dakwah Nabi Di Era Multimedia, h. 169.

${ }^{5}$ Kementerian Agama RI, Al-Qur'an dan Terjemahnya, h. 480.

${ }^{6}$ Firdaus Muhammad, Jurnalistik Profetik Konseptualisasi Dakwah Nabi Di Era Multimedia, h. 160.

${ }^{7}$ Firdaus Muhammad, Jurnalistik Profetik Konseptualisasi Dakwah Nabi Di Era Multimedia, h. 144.
} 
dalam posisi yang sulit untuk diakses oleh publik yang sudah menjadi bagian dari masyarakat budaya teknologi. Dalam hal ini, kehadiran teknologi sudah membantu bagi proses penyebaran pesan-pesan religius, dan melalui teknologi manusia modern saat ini bisa menutupi keterbatasannya, sehingga mereka masih bisa mengakses dan mengonsumsi pesan-pesan agama disela-sela kesibukannya sebagai manusia modern.

Salah satu perkembangan teknologi yakni munculnya media sosial yang menawarkan banyak cara atau metode untuk menyampaikan pesan dakwah. Kabupaten Bone menjadi salah satu kabupaten yang masyarakat milenialnya sudah banyak menggunakan media sosial. Masyarakat milenial tersebut memiliki kecenderung menggunakan media sosial sebagai media untuk mendengarkan dan menyaksikan dakwah Islam pada media sosial yang dimilikinya. Sehingga pengguna dengan mudah mengakses informasi mengenai keagamaan khususnya dalam hal pembelajaran tentang agama Islam. Terkait hal ini, maka penulis tertarik untuk meneliti Resepsi Masyarakat Milenial terhadap Pesan Dakwah Melalui Media Sosial di Kabupaten Bone.

\section{METODE PENELITIAN}

Penelitian ini merupakan jenis penelitian fenomenologi dengan pemaparan data secara kualitatif. Data diperoleh dari informan yang terdiri dari masyarakat milenial Kabupaten Bone yang terdiri dari 5 kecamatan, diantaranya Kecamatan Tanete Riattang, Kecamatan Tanete Riattang Barat, Kecamatan Tanete Riattang Timur, Kecamatan Palakka, dan Kecamatan Awangpone . Pengumpulan data dilakukan dengan metode observasi dan wawancara dengan bantuan instrumen berupa pedoman wawancara. Analisis data dilakukan dengan reduksi data, penyajian data/Disolay data, dan penarikan kesimpulan.

\section{PEMBAHASAN}

Masyarakat milenial dikenal sangat ketergantungan dengan internat, senang menghabiskan hidupnya di jejaring media daring, dan selalu mengikuti perkembangan teknologi informasi dan komunikasi dalam rangka pemanfaatan teknologi mutakhir untuk memudahkan aktivitas sehari-hari. Generasi ini melihat dunia, tidak secara langsung melainkan mereka berselancar di dunia maya. Mulai dari berkomunikasi, berbelanja online dan mendapatkan informasi dan kegiatan lainnya. Banyak dari kalangan millennial melakukan semua komunikasi melalui text messaging atau chatting dunia maya dengan membuat akun media sosial seperti Facebook, WhatsApp, Instagram Youtube dan sebagainya.

Semua manusia mempunyai kebutuhan untuk terhubung dan berinteraksi dengan satu sama lain. Media sosial sebagai media komunikasi dikembangkan untuk membantu orang untuk memenuhi kebutuhan itu. Kehadiran media sosial membuat manusia dapat berbagi perspektif, wawasan, pengalaman, dan opini yang satu dengan yang lainmelalui Blog, Wiki, papan pesan, dan video. Di sini partisipasi dari komunitas orang-orang dan masyarakat pada umunya telah memberikan dorongan bagi pemenuhan kebutuhan dimaksud, dan lebih jauh dari itu membentuk jaringan media sosial. Kini, hampir tidak ada seorangpun yang tidak berpartisipasi dalam satu atau lebih jenis media sosial, baik itu sekadar bertukare-mail, 
menggunakan fasilitas chat atau posting foto bertukar musik. ${ }^{8}$

Dakwah pada masyarakat era milenial ini benar-benar harus memanfaatkan media, utamanya media-media baru. Perkembangan teknologi komunikasi telah mengubah cara orang berkomunikasi. Saat ini, hampir setiap orang menggunakan internet dalam mengirim, mencari, dan membaca informasi. Dalam berinteraksi pun kebanyakan melalui sosial media disbanding komunikasi secara langsung. Hal ini sangat dimungkinkan terjadi setidaknya dipengaruhi beberapa faktor, antara lain pesatnya perkembangan teknologi informasi dan komunikasi, juga kecenderungan masyarakat milenial yang sangat bergantung pada media. Kaitannya dengan dakwah, peran media sangat strategis dalam upaya penyampaian pesan dakwah. Media mampu menembus batas-batas ruang dan waktu. ${ }^{9}$

\section{Model Dakwah Multimedia Di Media Sosial}

Model dakwah multimedia di media sosial saat ini memiliki banyak variasi yang memungkinkan masyarakat untuk mendengarkan dakwah kapan pun dan dimanapun mereka berada. Sehingga tidak ada kata tidak memiliki kesempatan atau waktu karena semuanya bisa dilakukan melalui smartphone yang dimiliki.

Pendakwah multimedia menyampaikan pesan salah satunya melalui media sosial, seperti facebook, youtube, whatsapp dan sebagainya semakin marak. Hal itu didasarkan pada peningkatan penggunaan media teknologi canggih yang banyak beredar di kalangan masyarakat umum.

Faktor yang membuat terjadinya peningkatan yang sangat signifikan terhadap perkembangan dakwah adalah adanya wadah dakwah yang siap meneruskan risalah Rasulullah dengan model-model dakwah yang mereka gunakan, sesuai dengan kreatifitas dan perkembangan zaman.

\section{Audio Visual (Video)}

Audio visual merupakan model dakwah yang menampilkan suara dan gambar (dalam bentuk video). Biasanya dai yang aktif di media sosial menmembagikan ceramahnya melalui video dengan durasi yang cukup singkat.

Banyak dakwah berbentuk video yang bisa didapatkan di media sosial, karena kecenderungan masyarakat untuk membuka media sosial yang dimilikinya. Sehingga mudah untuk mengakses dakwah yang diinginkan dan lebih mudah dilihat karena bisa dilakukan pada saat santai. Jadi dapat melihat video-video dakwah dalam kondisi apapun sesuai kebutuhan.

Video yang diunggah melalui media sosial biasanya video yang berdurasi lama, namun karena video tersebut ingin dibagikan ke teman atau kerabat maka perlu diringkas atau dipangkas, mengambil inti dari dakwah yang disampaikan. Sehingga pengguna atau penerima pesan dakwah di media sosial tidak jenuh terhadap model dakwah yang disajikan karena sesuai dengan minat masyarakat sekarang. Melalui peranan media sosial sebagai sarana penyampai dakwah memberi kemudahan masyarakat khalayak untuk mengaplikasikan dakwah di media sosial.

${ }^{8}$ http://www.evancarmichael.com/Home-Based-Business/3010/4-Charakteristics-ofSocial-Media-Optimization-vs-SEO.html (diakses pada 27 Maret 2013)

${ }^{9}$ Muhammad Habibi, Optimalisasi Dakwah Melalui Media Sosial Di Era Milenial, AlHikmah: Jurnal Dakwah, Institut Agama Islam Negeri (IAIN) Pontianak Volume 12, Nomor 1, Tahun 2018, h. 102. 


\section{Gambar}

Model dakwah yang berbentuk gambar adalah suatu media visual yang hanya dapat dilihat saja akan tetapi tidak mengandung unsur suara atau audio. Model dakwah melalui gambar ini memiliki daya tarik tersendiri bagi pengguna media sosial, karena dapat mempermudah dan dan memperjelas pemahaman sesuatu yang penting atau yang ingin disampaikan kepada penerima.

Media sosial berperan sebagai perantara yang menghubungkan antara dai dengan mad'u. Pemahaman pesan yang diterima oleh mad'u biasanya lebih ditentukan oleh pemahaman dan keterampilan mad'u untuk menginterpretasikan pesan dakwah yang tertulis tersebut.

3. Tulisan

Tulisan adalah kumpulan huruf-huruf atau angka yang dituliskan dalam suatu bahasa tertentu. Tulisan ditampilkan dalam bentuk teks dan bukan gambar. Tulisan bisa dirangkai menjadi kata-kata yang indah dan mampu menarik pembaca dengan begitu cepat. Dengan penyusunan kata yang tepat akan memberi kesan yang bagus kepada pembaca.

Model dakwah yang berbentuk tulisan ini, menjadi salah satu bentuk yang disenangi oleh kaum muda atau masyarakat milenial saat ini. Karena itu, dakwah tidak hanya berupa gambar atau video yang menyampaikan dakwah secara tatap muka tetapi dakwah melalui tulisan juga mampu memberi pengetahuan keagamaan, dengan teknik penulisan dan pemilihan kata yang tepat dapat menarik perhatian pembaca.

Sebagai pengguna media sosial yang aktif di media sosial membuat masyarakat tertarik dengan model dakwah yang berbentuk tulisan, karena penjelasan yang simple dan mudah dipahami membuat saya lebih senang dengan bentuk dakwah ini. Misalnya salah satu akun dakwah diikuti di instagram selalu memposting dakwah yang berbentuk tulisan dan mengikutsertakan penjelasanpenjelasan terkait pesan-pesan dakwah yang disampaikan melalui tulisannya tersebut. Sehingga lebih mudah paham dan juga disertai ayat-ayat atau hadits yang terkait dengan pesan dakwahnya.

Bentuk dakwah tulisan sangat efektif, di samping itu berdakwah lewat tulisan bisa dilakukan oleh semua orang, tanpa terkecuali. Mulai anak-anak, remaja, dewasa, orang tua, maupun yang sudah lanjut usia. Semuanya mempunyai hak kesempatan yang sama. Sehingga semua orang mempunyai kesempatan yang sama untuk menyebarkan kebaikan atau berdakwah lewat tulisan.

Berdakwah di media sosial bisa juga dilakukan melalui bentuk tulisan yang mengajak teman-teman untuk senantiasa berbuat kebaikan dan sebagai wadah untuk saling mengingatkan ke jalan yang benar. Setiap postingan diusahakan memiliki unsur kebaikan dan mempergunakan media sosial sebagai sarana mempererat tali silaturahmi bukan malah saling menjatuhkan.

\section{Penerimaan Dakwah Masyarakat Milenial Terhadap Pesan Multimedia Melalui Media Sosial}

Masyarakat adalah salah satu unsur dalam proses kehidupan demokrasi. Masyarakat mampu berpikir berdasarkan alasan-alasan yang ilmiah dan logis. Apalagi kemampuan masyarakat dalam melihat dari perspektif yang berbeda juga muncul dari latar belakang sosial budaya, sehingga tampak bahwa mereka mampu melihat persoalan secara kritis. Mereka memaknai informasi yang diperolehnya sesuai dengan pengetahuan dan pengalaman yang dimilikinya.

Pendakwah multimedia menyampaikan pesan salah satunya melalui media sosial, seperti facebook, youtube, whatsapp, instagram dan sebagainya semakin marak. Hal itu didasarkan pada peningkatan penggunaan media teknologi canggih yang banyak beredar dikalangan masyarakat umum. 


\section{Pandangan Masyarakat Milenial terkait Dakwah di Media Sosial}

Ketertarikan seseorang dalam menggunakan media sosial sebagai media komunikasi salah satunya karena kepopuleran media ini dan ketersedian informasi yang banyak ditemukan oleh orang-orang yang mencari informasi.

Disadari atau tidak, media dalam penggunaan komunikasi terutama media massa telah memberikan dampak positif yaitu meningkatkan intensitas, kecepatan dan jangkauan komunikasi yang dilakukan manusia dalam berbagai hal. Termasuk dalam hal ini tak ketinggalan adalah dalam komunikasi dakwah di media sosial.

Dakwah di media sosial terkesan menarik, kekinian dan sangat membantu. Memanfaatkan media sosial sebaik mungkin, misalnya men-share video-video dakwah ke media sosial atau memposting caption-caption dakwah singkat. Dakwah di media sosial harus sudah mulai dilirik dan diperhatikan seksama. Sebab perkembangan zaman menuntut hal itu sehingga kaum muda yang jarang ke mesjid dapat tersentuh dakwah. Namun harus diperhatikan seperti dakwah yang kita dengarkan. Bukan dakwah yang tidak jelas latar belakang dainya. Serta harus cerdas dalam menerima dakwah.

Dengan hadirnya media sosial di tengah-tengah masyarakat, mengharuskan seorang pengembang dakwah harus dapat beradaptasi dengan media sosial tersebut. Seorang pendakwah mesti melakukan desain ulang formulasi komunikasi dakwahnya, yang bisa mengimbangi perkembangan teknologi media yang berbasis jaringan internet.

Penerima dakwah hanya bisa menerima saja, tanpa ada timbal balik atau proses komunikasi antara pendakwah dan yang didakwahi. Dakwah yang menarik yaitu ketika ada feedback atau tanya jawab agar bisa menambah khasanah keilmuan tentang agama.

Media sosial merupakan salah satu media yang terbaik untuk mempopulerkan, mengajarkan, memantapkan, atau mengingatkan sesuatu dalam dakwah. Keuntungan dakwah dengan menggunakan media massa adalah bahwa media massa menimbulkan keserempakan, artinya suatu pesan dapat diterima oleh komunikan yang jumlahnya relatif amat banyak. Jadi untuk menyebarkan informasi media masa sangat efektif dalam mengubah sikap, perilaku, pendapat komunikan dalam jumlah yang banyak.

\section{Penerimaan Pesan Dakwah Multimedia di Media Sosial}

Jejaring sosial menjadi tantangan dan tuntunan dalam mewacanakan doktrin agama secara super-interaktif. Di mana pemaknaan individu terhadap teks atau pesan dapat sangat mempengaruhi atau mendominasi motivasi individu dan atau komunitas dalam berperilaku. Dai masa depan adalah dari multidimensi, multimedia, multi interdisipliner yang mampu menarik khalayak terhadap pesan dakwah yang diciptakannya.

Sangat antusias karena bisa diakses kapan saja, bisa memilih tema yang diinginkan. Dakwah yang lugas tapi santai. kemudahan mengakses itu menjadi daya tarik. Kemudian banyak pilihan, artinya kita disajikan banyak pilihan dakwah kita mau pilih apa dan bisa melakukan perbandingan dari berbagai aliran. Karena banyak pilihan yang dapat diakses dengan mudah.

Al-Qur'an memiliki pandangan di balik kemudahan dan kecepatan dalam publikasi berita atau informasi pada media online yang dijelaskan dalam QS. alHujurat/49: 6. 


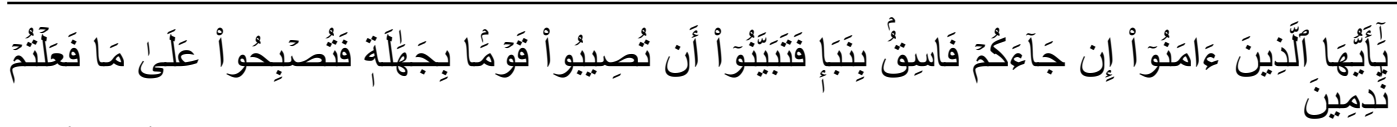

Terjemahnya:

Hai orang-orang yang beriman, jika datang kepadamu orang fasik membawa suatu berita, maka periksalah dengan teliti agar kamu tidak menimpakan suatu musibah kepada suatu kaum tanpa mengetahui keadaannya yang menyebabkan kamu menyesal atas perbuatanmu itu. ${ }^{10}$

Ayat tersebut merupakan salah satu dasar yang ditetapkan agama dalam kehidupan sosial sekaligus merupakan tuntunan dalam memaknai sebuah informasi. Kehidupan manusia dan interaksinya haruslah didasarkan pada sesuatu yang diketahui dengan jelas. Manusia sendiri tidak dapat menjangkau seluruh informasi. Karena itu, membutuhkan pihak lain. Pihak lain itu ada yang jujur dan memiliki integritas sehingga hanya menyampaikan hal-hal yang benar, dan adapula sebaliknya. Manusia harus mempertimbangkan informasi yang diterima, karena khawatir seseorang melangkah tidak dengan jelas atau dalam bahasa ayat di atas $b i$ jahalah. Ayat di atas menuntut manusia untuk menerima informasi berdasarkan pengetahuan sebagai lawan dari jahalah yang berarti kebodohan, di samping melakukannya berdasar pertimbangan logis dan nilai-nilai yang ditetapkan Allah swt. Banyaknya orang yang mengedarkan informasi atau isu bukan menjadi jaminan kebenaran informasi tersebut.

Penerimaan dakwah di media sosial bisa iya dimengerti bisa tidak. Kapan "iya" ketika konten dakwah yang ditonton memang dibuat khusus untuk masyarakat dunia maya. Pendek tapi padat. Tidak semua dakwah dapat dipahami dengan jelas, karena ada banyak juga pendakwah yang berbeda pandangan dengan pendakwah yang lain.

Transformasi bentuk dakwah sedikit mengalami perubahan di media sosial, terkait interaksi antara dai dengan $m a d$ ' $u$ yang menyampaikan pesan-pesan dakwah terkait tujuan hidup seorang manusia. Hal ini dapat disaksikan pada bentuk dakwah yang menggunakan media lisan. Apabila merujuk kepada term yang secara common sense (umum) merespresentasikan bahwa da'wah bil lisan menggambarkan seorang dai yang berinteraksi langsung dengan mad'u, berubah menjadi dakwah yang dikemas dalam bentuk video tersebut ke akun media sosialnya, dan memberikan kesempatan kepada mad'u (khalayak) untuk mengomentarinya.

Medium dakwah di era modern dan multimedia ini, tidak lagi seorang pengembang dakwah bertumpu pada pola dakwah klasik, dengan mengandalkan podium-podium, tablik akbar dan tautsiah-tautsiah. Tidak lagi menunggu waktu atau musim berganti misalnya berdakwah atau berkhotbah di hari jum'at, safari ramadhan, tahlilan dan acara-acara seremoni lainnya.

Pendakwah multimedia menyampaikan pesan salah satunya melalui media sosial, seperti facebook, youtube, whatsapp, blackberry, messanger dan sebagainya semakin marak. Hal itu didasarkan pada peningkatan penggunaan media teknologi canggih yang banyak beredar dikalangan masyarakat umum.

Sebagai media yang sedang trend dalam penggunaanya untuk menyampaikan pesan dakwah, akan mengundang banyak Dai untuk berkontribusi dalam dakwah melalui media sosial. Semua media pada dasarnya diusahakan untuk dibuat secara sempurna. Setiap media memiliki kelebihan dan kekurangan jika dibandingkan dengan media-media yang lain. Dengan kelebihan dan kekurangan itu timbullah dampak yang akan dirasakan.

Media sosial memiliki dampak positif apabila dimanfatkan dengan baik,

${ }^{10}$ Kementerian Agama RI, Al-Qur'an dan Terjemahnya (Jakarta: Direktorat Jenderal Bimbingan Masyarakat Islam dan Urusan AgamaIslam dan Bimbingan Syariah, 2012), h. 516. 
yaitu:

1. Dakwah melalui media sosial merupakan alternatif dakwah selain dakwah secara langsung, bertatap muka.

2. Instagram merupakan media sosial yang paling banyak penggunanya di Indonesia. Hal ini menjadi peluang besar bagi dakwah. Karena tujuan utama dakwah lewat media sosial adalah diakses (dibaca, dilihat dan di dengar) oleh orang lain.

3. Sebagai salah satu media jejaring sosial, media sosial cukup akrab bagi penggunanya, hal tersebut dimanfaatkan dalam kegiatan dakwah di instagram, baik dai yang sudah profesional maupun dai dadakan dapat menyampaikan dakwah dengan gaya sendiri ke media sosial yang ringan dan tidak terkesan menggurui. Begitu pula dari sudut mad'u dapat merasa rileks tidak dalam ruang yang formal karena tidak bertemu dan tatap muka. Sehingga terjadi feedback yang bersifat terbuka.

Media sosial memiliki kekurangan dalam penyampaian dakwah, yaitu:

1. Memberikan dampak negatif apabila tidak dilakukan dengan baik-dan benar.

2. Dakwah yang dilakukan di media sosial mengurangi kontak langsung tatap muka antara da'i dan mad'u.

3. Efek dari proses dakwah melalui instagram kurang bisa diamati secara maksimal, karena bersifat maya.

Banyak sekali fitur dari media sosial yang bisa dijadikan media dakwah yang dapat kita ambil pelajarannya, seperti pesan dakwah yang disampaikan langsung fokus pada sasaran yang dituju, mudahnya akses pesan dakwah tanpa harus kesana-kemari, terlebih materi yang disampaikan juga dikemas dengan menarik dan membuat kita senang melihatnya.

Karena dakwah sekarang milenial, mengikuti menyesuaikan perkembangan di masyarakat yang berubah sesuai era digital saat ini maka dakwah yang disebarkan melalui media sosial mendapatkan banyak perhatian masyarakat terutama kalangan pemuda, mahasiswa yang merupakan anak milenial cenderung melihat konten dakwah di media sosial.

Pendakwah profesional mampu menyelaraskan media audio dan visual secara interaktif interkonektif, didukung isi pesan yang dinamis, fleksibel dan kreatif. Media itu harus mengikuti kebutuhan mad'u. Media sosial yang telah menarik hati para penggunanya dalam berinteraksi sosial di dunia maya, akan eksis. Semakin menarik dan kreatif sebuah pesan dakwah, maka semakin memberi stimuli positif kepada mad'u dalam mempelajari, memahami dan mengamalkan ajaran Islam.

\section{SIMPULAN}

Model dakwah multimedia di media sosial saat ini memiliki banyak variasi yang memungkinkan masyarakat untuk mendengarkan dakwah kapan pun dan dimanapun. Model dakwah tersebut di antaranya Audio Visual/video, Gambar dan tulisan, dan Animasi. Audio visual merupakan model dakwah yang menampilkan suara dan gambar (dalam bentuk video). Biasanya dai yang aktif di media sosial men-membagikan ceramahnya melalui video dengan durasi yang singkat. Model dakwah yang berbentuk gambar adalah suatu media visual yang hanya dapat dilihat saja akan tetapi tidak mengandung unsur suara atau audio. Dakwah yang berbentuk animasi juga banyak ditampilkan di media sosial. Misalnya kartun-kartun yang 
bergerak yang memiliki pesan dakwah di dalamnya. Sehingga penerima pesan dengan mudah memahami maksud atau isi dari animasi tersebut.

Beberapa pengguna media sosial merasa dengan maraknya materi Islam yang diunggah di link media sosial, membuat masyarakat semakin tertarik mempelaiari Islam, merasa memiliki pemahaman yang semakin baik tentang Islam, dan merasa perilaku sehari-hari meniadi lebih sesuai dengan tuntunan Islam. Materi-materi Islam di media sosial juga dianggap membantu bagi mereka yang merasa memiliki keterbatasan waktu untuk hadir di forum kajian. Banyak di kalangan remaja dan orang tua yang menggunakan media sosial untuk melakukan hal positif seperti menyebarkan dakwah dan hal-hal kebaikan lainnya, pemanfaatan seperti inilah yang harusnya dilakukan oleh kalangan muda agar selalu menyampaikan kebaikan bukan malah sebaliknya. Dengan demikian, penggunaan multimedia merupakan alat bagi keberhasilan dakwah dari seorang dai. Oleh karena itu, dai harus menjadikan multimedia sebagai mitra dalam berdakwah.

\section{DAFTAR PUSTAKA}

Al Walidah, Iffah. "Tabayyun Di Era Generasi Millennial”, Jurnal Living Hadis, Vol. 2 Nomor 2 1, http://ejournal.uinsuka.ac.id/ushuluddin/Living/article/view/1359 Oktober, 2017.

Muh. Said, Nurhidayat. Dakwah dan Berbagai Aspeknya, Makassar: University Alauddin Press. 2013.

Fakhruroji, Moch. Dakwah di Era Media Baru: Teori dan Altivisme Dakwah di Internet. Bandung: Simbiosa Rekatama Media, 2017.

Muhammad, Firdaus Jurnalistik Profetik Konseptualisasi Dakwah Nabi Di Era Multimedia. Makassar: Alauddin University Press. 2013.

Agama RI, Kementerian. Al-Qur'an dan Terjemahnya. Jakarta: Direktorat Jenderal Bimbingan Masyarakat Islam dan Urusan Agama Islam dan Bimbingan Syariah, 2012.

http://www.evancarmichael.com/Home-Based-Business/3010/4-Charakteristicsof-Social-Media-Optimization-vs-SEO.html (diakses pada 27 Maret 2013)

Habibi, Muhammad. Optimalisasi Dakwah Melalui Media Sosial Di Era Milenial. Al-Hikmah: Jurnal Dakwah, Institut Agama Islam Negeri (IAIN) Pontianak Volume 12, Nomor 1, Tahun 2018. 